\title{
Epstein-Barr Nuclear Antigen 1 IgG Ab Measurement
}

National Cancer Institute

\section{Source}

National Cancer Institute. Epstein-Barr Nuclear Antigen 1 Ig G Ab Measurement. NCI

Thesaurus. Code C106518.

The determination of the amount of the Epstein-Barr nuclear antigen 1 IgG antibody present in a sample. 